\title{
Caracterização do Gene da Proteína Capsidial de Dois Isolados, Patologicamente Distintos e Sorologicamente Semelhantes, do Grapevine virus $B$ em Videiras no Estado de São Paulo*
}

\author{
Andreia E. Moreira ${ }^{1}$, José O. Gaspar ${ }^{1 * *}$, Luís Eduardo A. Camargo² \& Hugo Kuniyuki ${ }^{3 * *}$ \\ ${ }^{1}$ Departamento de Zoologia e Botânica, IBILCE-UNESP, CEP 15054-000, São José do Rio Preto, SP, e-mail: \\ gaspar@dzb.ibilce.unesp.br; ${ }^{2}$ Departamento de Entomologia, Fitopatologia e Zoologia Agrícola, ESALQ-USP, Cx. Postal 9 , \\ CEP 13418-900, Piracicaba, SP; ${ }^{3}$ IAC-Centro de Pesquisa e Desenvolvimento de Fitossanidade, CEP 13020-902, Campinas, SP
}

(Aceito para publicação em 10/10/2003)

Autor para correspondência: José Osmar Gaspar

MOREIRA, A.E., GASPAR, J.O., CAMARGO, L.E.A. \& KUNIYUKI, H. Caracterização do gene da proteína capsidial de dois isolados, patologicamente distintos e sorologicamente semelhantes, do Grapevine virus B em videiras no Estado de São Paulo. Fitopatologia Brasileira 29:075-080. 2004.

\section{RESUMO}

No presente trabalho, descreve-se a caracterização do gene codificador da proteína capsidial de dois isolados sintomatologicamente distintos do Grapevine virus B (GVB). Para isto, RNA totais foram extraídos de folhas e pecíolos de videiras (Vitis spp.) infetadas, cultivares Rubi (GVB-C $\left.{ }^{\mathrm{SP}}\right)$ e Itália $\left(\mathrm{GVB}-\mathrm{I}^{\mathrm{SP}}\right)$ e utilizados para amplificar, por RT/PCR, um fragmento entre as posições $6425 \mathrm{e}$ 7118 (694 nucleotídeos, nt) do RNA do GVB ("GenBank", acesso X75448). O fragmento obtido inclui o gene da proteína capsidial (594 nt) codificando 197 aminoácidos com massa molecular estimada em aproximadamente $21.600 \mathrm{Da}$. A seqüência do GVB-C ${ }^{\mathrm{SP}}$ apresentou maior similaridade de nucleotídeos e aminoácidos deduzidos com o isolado italiano (acesso X75448), enquanto que o GVB-I ${ }^{\mathrm{SP}}$ foi mais similar a um outro isolado brasileiro do GVB descrito no Rio Grande do Sul (GVB ${ }^{\mathrm{BR} 1}$, acesso AF438410). Os dois isolados paulistas do GVB podem ser diferenciados por digestão com a enzima de restrição EcoRI, uma vez que há um sítio interno no GVB-C ${ }^{\mathrm{SP}}$ que está ausente no isolado GVB-I ${ }^{\mathrm{SP}}$.

Palavras-chave adicionais: Vitivirus, Vitis spp., fendilhamento cortical, "grapevine corky bark", "grapevine rugose wood", complexo do lenho rugoso.

\section{ABSTRACT}

Characterization of the coat protein gene of two isolates, pathologically distinct and serologically similar, of Grapevine virus $B$ in corky bark-affected grapevines in São Paulo State, Brazil

The present work describes the characterization of the coat protein gene of two isolates of Grapevine virus $B$ (GVB), which can be differentiated by their biological behavior on some grape cultivars. The total RNA was extracted from leaves and petioles of infected grapevines (Vitis spp.) of the cultivars Rubi (GVB-C ${ }^{\mathrm{SP}}$ ) and Italy (GVB-I ${ }^{\mathrm{SP}}$ ) and used to amplify, by RT/PCR, a fragment between positions 6425 and 7118 (694 nucleotides, nt) of the genomic RNA (GenBank, access X75448). The fragment comprises the coat protein gene (594 nt) coding for 197 amino acids with a predicted $\mathrm{Mr}$ of $21,600 \mathrm{Da}$. The sequence of GVB-C ${ }^{\mathrm{SP}}$ showed a greater similarity of nucleotides and deduced amino acids with the Italian isolate (access $\mathrm{X} 74448$ ), while the GVB-I ${ }^{\mathrm{SP}}$ was similar to a Brazilian isolate described in the State of Rio Grande do Sul , Brazil (GVB ${ }^{\mathrm{BR} 1}$, access AF438410). The isolates GVB-C $\mathrm{C}^{\mathrm{SP}}$ and GVB-I ${ }^{\mathrm{SP}}$ can be differentiated by digestion with the enzyme EcoRI, since this restriction site is present on the GVB-C $\mathrm{C}^{\mathrm{SP}}$ but absent on GVB-I ${ }^{\mathrm{SP}}$.

\section{INTRODUÇÃO}

As principais viroses de videira (Vitis spp.) descritas em outros países já foram constatadas no Brasil, constituindo um dos mais importantes problemas fitossanitários da viticultura nacional por resultarem em um decréscimo na produção de uva ou mesmo perdas totais, dependendo da variedade envolvida e da doença em questão (Amorim \& Kuniyuki, 1997). Dentre essas viroses, destacam-se aquelas

\footnotetext{
Apoio financeiro: FAPESP, CAPES

* Seqüências depositadas no GenBank com os números de acesso AY340582 e AY340583

**Bolsista do CNPq
}

constituintes do complexo do lenho rugoso, caracterizadas por alterações no cilindro do lenho das cultivares sensíveis de Vitis spp. (Savino et al., 1989; Minafra, 2000).

Das quatro doenças do complexo do lenho rugoso, o fendilhamento cortical ("grapevine corky bark") parece ser a mais comum (Kuniyuki \& Costa, 1982). Esta virose, descrita pela primeira vez na Califórnia (Hewitt, 1954), também foi detectada na Itália (Goidanich \& Canova, 1963), México (Teliz \& Goheen, 1968), Iugoslávia (Beukman \& Goheen, 1970), Brasil (Kuniyuki, 1975), Japão (Tanaka, 1976), França (Hevin et al. 1978), Austrália (Habili \& Symons, 2000) e Portugal (Santos et al., 2000). As principais características da doença são anormalidades no córtex que se torna excessivamente fendilhado e 
esponjoso e certas cultivares tintas de Vitis vinifera L. também apresentam avermelhamento nas folhas. A severidade da doença varia bastante, pois algumas cultivares reagem fortemente a infecção e outras não apresentam sintomas definidos ou simplesmente não os exibem (Goheen, 1988). Segundo Tanne et al. (1990), a perda na produção de uva é proporcional à severidade dos sintomas e, dependendo do porta-enxerto, pode haver redução de até $93.3 \%$ em relação às sadias. Embora determinações experimentais não tivessem sido feitas no Brasil, as cultivares mais sensíveis de $V$. labrusca, como Niagara Branca e Niagara Rosada apresentam acentuada redução na produção de uva e quase nada produzem, se muito afetadas (Kuniyuki \& Costa, 1982). O GVB ocorre simultaneamente com outros vírus da videira, mas a formação de complexos induzindo alterações sintomatológicas ou sinergismo ainda não é conhecida. O fendilhamento cortical é causado por um vírus de, aproximadamente, $800 \mathrm{~nm}$ de comprimento, denominado vírus B da videira (Grapevine virus $B$, GVB), gênero Vitivirus (Boscia et al., 1993; Bonavia et al., 1996; Martelli et al., 1997).

O GVB é um vírus restrito ao floema de sua única hospedeira natural, a videira, sendo perpetuado por multiplicação vegetativa, estaquia, união de tecidos (Kuhn, 1992; Martelli, 2000), e também disseminado por cochonilhas brancas (Pseudococcus spp. e Planococcus spp.) (Boscia et al., 1997). Pode ainda ser transmitido mecanicamente, com grande dificuldade, para espécies do gênero Nicotiana. O genoma do GVB consiste de um RNA de fita única com 7599 nucleotídeos e polaridade positiva com cinco "open reading frames" (ORF) codificando proteínas de $194 \mathrm{kDa}$ (replicase), $20 \mathrm{kDa}$ (função desconhecida), 31-36 kDa (movimento), 21-23 kDa (proteína capsidial) e 10-14 kDa (proteína de ligação ao RNA)(Saldarelli etal., 1996).

No Brasil, o fendilhamento cortical foi constatado pela primeira vez no Estado de São Paulo (Kuniyuki, 1975) e posteriormente no Rio Grande do Sul (Kuhn, 1992), sendo sua identificação feita por videiras indicadoras, teste sorológico ELISA (Kuniyuki et al., 2000) e no Rio Grande so Sul, recentemente, por sequenciamento do gene da proteína capsidial (Nickel et al., 2002). No Estado de São Paulo, o fendilhamento cortical ocorre com incidência de até $20 \%$, dependendo da cultivar (Kuniyuki \& Costa, 1982), enquanto que no Rio Grande do Sul, algumas plantações apresentam incidência superior a $60 \%$ (Kuhn, 1992). Nos vinhedos paulistas, dois isolados do GVB foram identificados. O isolado comum (GVB-C ${ }^{\mathrm{SP}}$ ) induz sintomas na cultivar indicadora LN-33 e em cultivares americanas ( . labrusca) como Concord, Isabel e Niagara, e o isolado Itália (GVB-I $\left.{ }^{\mathrm{SP}}\right)$, menos freqüente, causa reação mais forte em $\mathrm{LN}-33$, mas é assintomático nessas cultivares americanas. Foi determinado, mediante testes imunoenzimáticos, que estes dois isolados sintomatologicamente distintos são sorologicamente semelhantes (Kuniyuki et al., 2000). No presente trabalho, descreve-se a caracterização do gene codificador da proteína capsidial dos isolados comum e Itália do GVB encontrados no Estado de São Paulo.

\section{MATERIALEMÉTODOS}

\section{Extração de RNA total}

Para a extração de RNA total, foram utilizadas plantas de $V$. vinifera cv. Itália infetada com o GVB-I ${ }^{\mathrm{SP}}$ e cv. Rubi infetada com o GVB-C ${ }^{\mathrm{SP}}$, além de plantas não infetadas de ambas as cultivares que foram utilizadas como controle. Foram extraídos RNA totais dessas amostras utilizando-se o método de MacKenzie et al. (1997), que consiste no congelamento dos tecidos ( $1 \mathrm{~g}$ de nervuras e pecíolos) com $\mathrm{N}_{2}$ líquido, trituração e extração com 5,0 $\mathrm{ml}$ de tampão (isotiocianato de guanidina 4 $\mathrm{M}$, acetato de sódio 0,2 M pH 5,0, EDTA $25 \mathrm{mM}$ e PVP-40 2,5\%), 0,5 ml de sarcosil $20 \%$ e $0,05 \mathrm{ml}$ de $\beta$-mercaptoetanol. Essa mistura foi aquecida a $70{ }^{\circ} \mathrm{C}$ por $10 \mathrm{~min}$, resfriada a temperatura ambiente e aplicada em uma coluna do kit "RNAeasy Plant Mini”, conforme especificação do fabricante (Qiagen).

\section{RT/PCR ("Polymerase Chain Reaction")}

A partir dos RNA totais obtidos, procedeu-se a síntese do DNA complementar (cDNA) utilizando-se os oligonucleotídeos CN47, CN54 e CN55 (Pappu et al., 1993), complementares à região 3' terminal de RNA virais poliadenilados. A reação (20 $\mu 1)$ envolveu uma desnaturação inicial do RNA total (200 ng) e dos oligonucleotídeos $(10 \mu \mathrm{g} / \mathrm{ml}$ cada $)$ a $95^{\circ} \mathrm{C}$ por $5 \mathrm{~min}$ com posterior resfriamento em mistura gelo/álcool. Em seguida, adicionaram-se os outros componentes da reação: tampão (Tris$\mathrm{HCl} 50 \mathrm{mM} \mathrm{pH} 8,3$ e KCl $5 \mathrm{mM}$ ), DTT 10 mM, MgCl 3 mM, 0,2 $\mathrm{mM}$ de cada dNTP, 1 unidade de inibidor de RNAse e 200 unidades de transcriptase reversa (Superscript II RNAse H; Gibco-BRL). Para a síntese do cDNA, essa mistura foi incubada a $42{ }^{\circ} \mathrm{C}$ por $2 \mathrm{~h}$.

Um par de oligonucleotídeos foi desenhado com o auxílio dos programas Primer-3 e Oligo-4 utilizando como molde a seqüência do isolado italiano (Saldarelli et al., 1996), visando a clonagem do gene amplificado em plasmídeo para posterior sequenciamento. As seqüências dos oligonucleotídeos desenhados são: 5'CAAGCAATTCCCCGAGAGT3' (senso) e 5'TTTAGCCGCACTCCTTGACT3' (antisenso). Este par de oligonucleotídeos flanqueia um fragmento de 694 nucleotídeos (nt 6425 ao 7118) que inclui o gene codificador da proteína capsidial (594 nt).

Na reação da PCR, para um volume final de $50 \mu 1$, foram misturados $5 \mu \mathrm{l}$ de tampão (Tris-HCl 20 mM pH 8,4; KCl 50 $\mathrm{mM}) ; 3,5 \mathrm{mM}$ de $\mathrm{MgCl}_{2} ; 0,2 \mathrm{mM}$ de cada dNTP; $10 \mu \mathrm{g} / \mathrm{ml} \mathrm{de}$ cada oligonucleotídeos (senso e antisenso), $2 \mu 1$ da reação de cDNA e 3 unidades de Taq DNA polimerase (Invitrogen). As condições para o ciclo da PCR incluiram uma desnaturação inicial a $94^{\circ} \mathrm{C}$ por $4 \mathrm{~min}$, seguida de 30 ciclos a $94^{\circ} \mathrm{C}$ por $1 \mathrm{~min}$, $45^{\circ} \mathrm{C}$ por 1 min e $72^{\circ} \mathrm{C}$ por $2 \mathrm{~min}$, com uma extensão final a $72^{\circ} \mathrm{C}$ por $10 \mathrm{~min}$. Os fragmentos de DNA amplificados foram visualizados em gel de agarose a $1 \%$ ao lado do marcador 100 pb DNA Ladder (Gibco-BRL) corados com brometo de etídeo $(1 \mu \mathrm{g} / \mathrm{ml})$ sob luz ultravioleta.

\section{Clonagem e Seqüenciamento}

Os fragmentos obtidos foram clonados em vetor 
utilizando-se o kit "TOPO TA Cloning", segundo instruções do fabricante (Invitrogen). Após confirmação dos clones positivos por PCR, o plasmídeo recombinante foi extraído utilizando-se o kit "Concert Rapid Plasmid Miniprep System" (Gibco-BRL), seguindo-se digestão enzimática com EcoRI para comprovar novamente a formação do recombinante.

Os plasmídeos recombinantes foram sequenciados nos dois sentidos de leitura utilizando os oligonucleotídeos universais M13F e M13R e o kit "DNA sequencing Big Dye Terminator Cycle Sequencing Ready Reaction” (Perkin Elmer) no sequenciador ABI Prism 377 (Applied Biosystems Inc.). As seqüências obtidas foram inicialmente analisadas pelo algoritmo BLAST (http://www.ncbi.nlm.nih.gov), seguido do alinhamento das seqüências consenso pelo programa Multalin (http:// www.prodes.toulouse.inra.fr/multalin/multalin.html). Para dedução da seqüência de aminoácidos da proteína capsidial foi utilizado o programa Translate (http://www.expasy.org/tolls/ dna.html) e as relações filogenéticas foram estabelecidas por parcimônia com o auxílio do programa PAUP v.4.0b10, com análise de "bootstrap" de 500 réplicas. A construção gráfica da árvore foi feita pelo programa Tree View 1.6.1.

\section{RESULTADOS E DISCUSSÃO}

Um fragmento de DNA de tamanho esperado (694 pb), que inclui o gene codificador da proteína capsidial (CP) do GVB, foi amplificado via RT/PCR a partir de videiras com sintomas de fendilhamento cortical infetadas por um dos isolados GVB-C $\mathrm{C}^{\mathrm{SP}}$ ou GVB-I ${ }^{\mathrm{SP}}$. Não foram observados fragmentos de tamanhos inespecíficos e nem produtos amplificados a partir da amostra de plantas não infetadas (dados não mostrados). Esses resultados comprovam a relação de ambos os isolados com a doença fendilhamento cortical e evidenciam que a técnica de RT/PCR pode ser utilizada de forma confiável para o diagnóstico do GVB em substituição a testes de menor sensibilidade.

Problemas, por exemplo, na confiabilidade de testes sorológicos, tais como o ELISA para a detecção dos vírus do gênero Vitivirus são principalmente devidos a anti-soros com baixo título resultantes da baixa antigenicidade viral, a distribuição irregular do vírus na planta hospedeira e a variação do título viral nas diferentes estações do ano (Boscia et al., 1992; Minafra, 2000). Quanto a PCR, alguns pesquisadores já vêm utilizando essa técnica ou variações desta, como a immunocaptura acoplada a PCR (IC/RT/PCR), com sucesso para a detecção de Vitivirus em tecidos de hospedeiras herbáceas ou videiras infetadas (Minafra et al., 1992; Minafra \& Hadidi, 1994; Minafra, 2000).

Visando a identificação e a caracterização dos dois isolados do GVB, os fragmentos de DNA amplificados foram clonados para o sequenciamento. Para a comprovação da formação do plasmídeo recombinante, o DNA plasmidial das colônias selecionadas foi extraído e digerido com a enzima EcoRI para a liberação do fragmento inserido. Essa metodologia padrão veio, entretanto, acrescentar resultados interessantes e não esperados devido à diferenciação no padrão de digestão enzimática entre os dois isolados. Dois fragmentos de aproximadamente 550 e $150 \mathrm{pb}$ foram liberados dos plasmídeos recombinantes obtidos para o GVB-C ${ }^{\mathrm{SP}}$, indicando a provável presença de um sítio interno de restrição para EcoRI no fragmento amplificado desse isolado. O sítio de restrição provavelmente estava ausente nos fragmentos obtidos do GVB-I ${ }^{\mathrm{SP}}$, pois houve a liberação do fragmento clonado inteiro (694 pb) (Figura 1). Pela análise de seqüências depositadas no "GenBank", dos outros isolados do GVB e de outros membros do gênero Vitivirus, verificou-se que o sítio de restrição também está presente no gene da $\mathrm{CP}$ do isolado italiano do $\mathrm{GVB}\left(\mathrm{GVB}^{\mathrm{It}}\right.$, acesso X75448) e do Heracleum latent virus (HLV, acesso X79270). Por outro lado, assim como no GVB-I ${ }^{S P}$, o sítio de corte para $E c o$ RI está ausente em um outro isolado brasileiro descrito no Rio Grande do Sul (GVB ${ }^{\mathrm{BR} 1}$, acesso AF438410), no isolado do Japão (GVB' ${ }^{\mathrm{Jp}}$, acesso AB039842), no vírus A da videira (Grapevine virus A, GVA, acesso X75433) e no vírus D da videira (Grapevine virus D, GVD, acesso Y07764). Dessa forma, um procedimento de digestão com $E c o$ RI de fragmentos amplificados contendo o gene da $\mathrm{CP}$ pode ser útil para a identificação dos isolados do GVB.

A partir do sequenciamento dos fragmentos clonados, obteve-se uma seqüência com 694 nucleotídeos para ambos isolados, dos quais 594 correspondem ao gene codificador da CP do GVB (Figura 2) com 197 aminoácidos deduzidos e massa molecular estimada em 21,600 Da para a proteína, valor similar aos descritos para os outros isolados já sequenciados (Martelli et al., 1997). A presença do sítio de digestão para EcoRI foi confirmada na seqüência do gene da CP do GVB-C ${ }^{\mathrm{SP}}$, entre os nucleotídeos 510 e 515 (Figura 2, sublinhado), estando alterado, como esperado, no GVB-I ${ }^{\mathrm{SP}}$.

A comparação da seqüência de nucleotídeos e de aminoácidos deduzidos dos isolados paulistas com a de outros isolados do GVB descritos em outras regiões geográficas revelou que o GVB-C $\mathrm{SP}^{\mathrm{SP}}$ apresenta uma similaridade muito alta com o isolado italiano $\left(\mathrm{GVB}^{\mathrm{It}}\right)$, tanto em relação à seqüência de nucleotídeos $(98,7 \%)$ quanto à de aminoácidos $(99,0 \%)$,

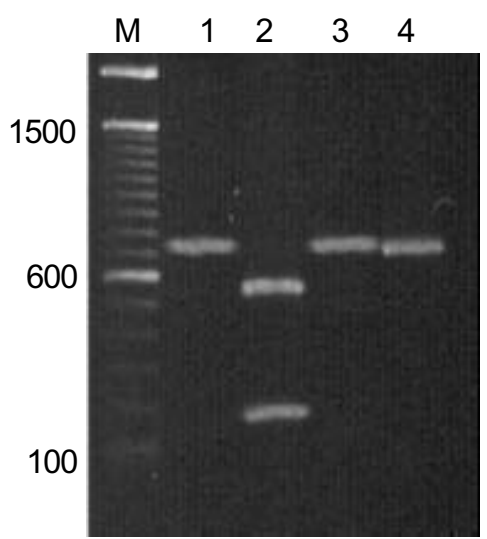

FIG. 1 - Análise dos produtos amplificados por PCR (1 e 3) e do corte enzimático com EcoRI do DNA amplificado do Grapevine virus $B$ (2 e 4) em gel de agarose a $1 \%$. 1 e $2:$ GVB-C ${ }^{\mathrm{SP}}, 3$ e $4:$ GVB-I ${ }^{\mathrm{SP}}$. M: marcador molecular 100 bp DNA Ladder (Invitrogen). 


\section{A.E. Moreira et al.}

\section{GVB-C}

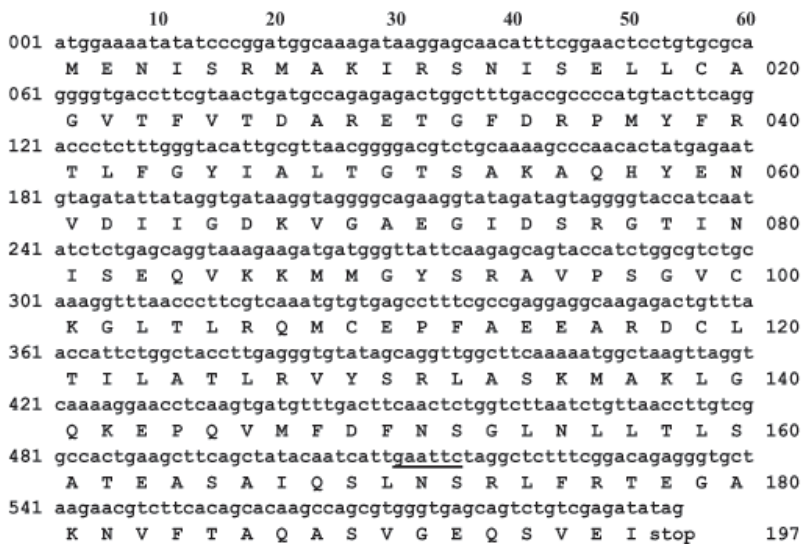

\section{GVB-1}

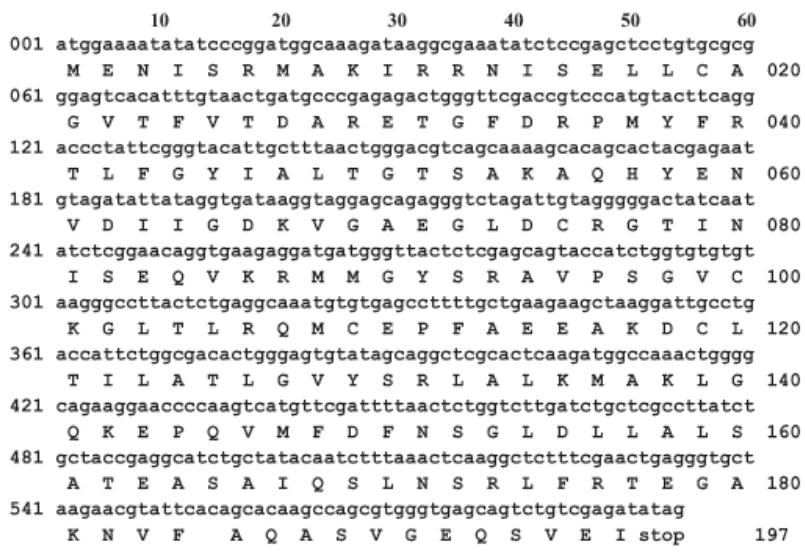

FIG. 2 - Seqüência de nucleotídeos (superior) e aminoácidos deduzidos (inferior) do gene da proteína capsidial dos isolados do Grapevine virus $B, \mathrm{GVB}^{\mathrm{SP}} \mathrm{C}^{\mathrm{SP}}$ GVB-I ${ }^{\mathrm{SP}}$. Seqüência sublinhada: sítio de restrição para $E c o$ RI

enquanto que o GVB-I ${ }^{\mathrm{SP}}$ é mais próximo ao isolado $\mathrm{GVB}^{\mathrm{BR} 1}$, com similaridades, respectivamente, de $92,4 \%$ e $95,9 \%$ na seqüência de nucleotídeos e aminoácidos (Tabela 1). O isolado japonês $\left(G^{\prime} B^{\mathrm{IP}}\right)$ foi o menos similar em relação aos isolados paulistas. Apesar das variações mais acentuadas na seqüência de nucleotídeos, a seqüência deduzida de aminoácidos não mostra grandes alterações entre os isolados das diferentes regiões, com similaridades entre $91,9 \%$ a $99,0 \%$, o que evidencia que a maioria das trocas de nucleotídeos não leva a mudanças no aminoácido especificado (substituições sinônimas). Como a proteína em questão é estrutural e provavelmente exerce um papel importante na especificidade em relação à única hospedeira natural, essas observações eram esperadas já que variações acentuadas na proteína capsidial poderiam ser deletérias para a espécie (Russo, 2001).

$\mathrm{Na}$ análise filogenética por parcimônia, foram utilizadas as seqüências de nucleotídeos (Figura 3A) e aminoácidos deduzidos (Figura 3B) da CP dos isolados do GVB e de outras
TABELA 1 - Comparação (similaridade em porcentagem) entre seqüências de nucleotídeos (abaixo da diagonal, em cinza) e aminoácidos deduzidos (acima da diagonal) da proteína capsidial dos isolados paulistas do do Grapevine virus $B$ (GVB) $\left(\mathrm{GVB}-\mathrm{C}^{\mathrm{SP}}\right.$ e $\left.\mathrm{GVB}-\mathrm{I}^{\mathrm{SP}}\right)$ e outros isolados depositados no GenBank*

\begin{tabular}{lccccc}
\hline & GVB-C $^{\text {SP }}$ & GVB-I $^{\text {SP }}$ & GVB $^{\text {It }}$ & GVB $^{\text {BR1 }}$ & GVB $^{\text {Jp }}$ \\
\hline GVB-C $^{\text {SP }}$ & --- & 94,9 & 99,0 & 97,5 & 94,4 \\
GVB-I $^{\text {SP }}$ & 83,2 & --- & 94,9 & 95,9 & 91,9 \\
GVB $^{\text {It }}$ & 98,7 & 82,2 & --- & 97,5 & 94,4 \\
GVB $^{\text {BR1 }}$ & 82,2 & 92,4 & 81,1 & --- & 94,9 \\
GVB $^{\text {Jp }}$ & 82,0 & 81,6 & 82,0 & 81,5 & --- \\
\hline
\end{tabular}

*Os números de acesso ao GenBank estão indicados entre parênteses. GVB-C $^{\mathrm{SP}}$ (AY340582); GVB-I ${ }^{\mathrm{SP}}$ (AY340583); GVB ${ }^{\mathrm{It}}(\mathrm{X} 75448) ;$ GVB $^{\mathrm{BR}}$ (AF438410); GVB ${ }^{\mathrm{Ip}}$ (AB039842).
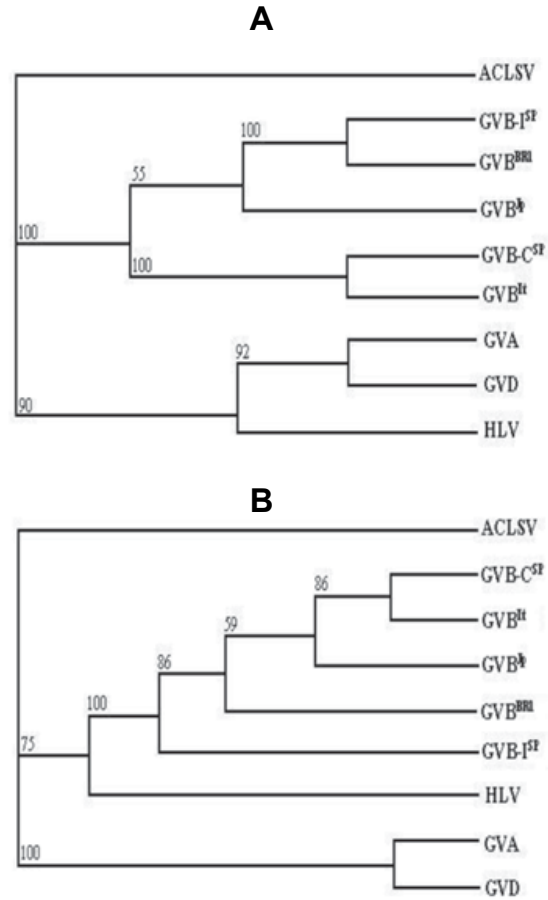

FIG. 3 - Dendogramas obtidos a partir da análise filogenética por parcimônia com base na seqüência completa de nucleotídeos (A) e de aminoácidos deduzidos (B) da proteína capsidial dos isolados do do Grapevine virus $B$ (GVB) e de outros membros do gênero Vitivirus. ACLSV pertence ao gênero Trichovirus e representa um grupo externo no dendograma. Os números de acesso ao GenBank para os vírus citados acima são: GVB-C ${ }^{\mathrm{SP}}$ (AY340582), GVBI ${ }^{\mathrm{SP}}$ (AY340583), GVB $^{\text {It }}$ (X75448), GVB ${ }^{\text {BR1 }}$ (AF438410), GVB ${ }^{\mathrm{Jp}}$ (AB039842), HLV (X79270), GVA (X75433), GVD (Y07764), ACLSV (NC001409)

espécies do gênero Vitivirus (GVA, GVD e HLV) que já haviam sido sequenciadas, além do Apple chlorotic leaf spot virus (ACLSV) gênero Trichovirus, utilizado como grupo externo. Em relação à seqüência de nucleotídeos (Figura 3A), o GVB$\mathrm{C}^{\mathrm{SP}}$ foi agrupado junto com o isolado italiano e o $\mathrm{GVB}-\mathrm{I}^{\mathrm{SP}}$ junto 
Caracterização do gene da proteína capsidial de dois isolados...

com o isolado $\mathrm{GVB}^{\mathrm{BR} 1}$, ambos em $100 \%$ das réplicas, confirmando os resultados anteriores de similaridade na seqüência de nucleotídeos (Tabela 1). Vale ressaltar que os isolados GVB-C $\mathrm{C}^{\mathrm{SP}}$ e $\mathrm{GVB}^{\text {It }}$ são os que possuem o sítio interno de restrição para $E c o$ RI, podendo ser diferenciados dos demais por produzir dois fragmentos quando o gene da $\mathrm{CP}$ é submetido a corte com essa enzima. Já nos isolados $\mathrm{GVB}^{\mathrm{IP}}, \mathrm{GVB}^{\mathrm{BR} 1}$ e GVB$\mathrm{I}^{\mathrm{SP}}$, que foram agrupados em um mesmo ramo, este sítio está alterado. Como observado anteriormente em relação aos outros membros do gênero, a espécie GVA é agrupada junto com o GVD em um número significativo de réplicas, enquanto o HLV é colocado em um ramo mais externo, embora um relacionamento sorológico distante entre o GVA e o GVD foi relatado por Choueiri et al. (1997).

Considerando-se a filogenia relativa à seqüência de aminoácidos, um padrão similar de agrupamento foi observado (Figura 3B), embora não tão marcante devido às menores diferenças encontradas na seqüência da proteína capsidial nos isolados do GVB. O que pode ser observado, é que todos os isolados de GVB constituem um grupo monofilético em 100\% das réplicas, o que denota ancestralidade comum.

A viticultura nacional é resultante da multiplicação de clones de cultivares tradicionais de copa e porta-enxerto, cujos materiais propagativos foram importados, há muitos anos, de países produtores, principalmente da Itália (Amorim \& Kuniyuki, 1997). Atualmente, a importação de mudas de videiras pelo Brasil ainda é praticada, porém, atendendo às exigências fitossanitárias. A análise conjunta das duas árvores filogenéticas mostra maior proximidade do GVB-C $\mathrm{CP}^{\mathrm{SP}}$ com o isolado oriundo da Itália, sendo que ambos induzem sintomas semelhantes em diversas cultivares de Vitis spp. (Amorim \& Kuniyuki,1997). Esses dados parecem indicar a introdução do GVB-C $\mathrm{C}^{\mathrm{SP}}$ no Brasil a partir de material propagativo importado da Itália.

O fato de o isolado paulista GVB-I ${ }^{\mathrm{SP}}$ ter maior proximidade com o isolado do Rio Grande do Sul pode indicar intercâmbio de material entre os dois Estados ou origem comum do material propagativo importado para estes Estados. Embora a similaridade de ambos com o isolado japonês seja menor do que em relação ao isolado italiano, os três primeiros são agrupados em um mesmo ramo na árvore filogenética de nucleotídeos, também inferindo origem comum (Figura 3A).

Embora estas conclusões sejam apenas especulativas, o fato do GVB-I ${ }^{\mathrm{SP}}$ ser assintomático em algumas cultivares americanas de Vitis spp., diferente dos isolados conhecidos até então, torna interessante um estudo mais abrangente sobre ele no que diz respeito aos outros genes virais e a ultraestrutura dos tecidos infectados para um melhor conhecimento da interação do vírus com a planta hospedeira.

\section{REFERÊNCIAS BIBLIOGRÁFICAS}

AMORIM, L. \& KUNIYUKI, H. Doenças da videira. In: Kimati, H., Amorin, L., Bergamin, A., Aranha, L.E.A. \& Rezende, J.A.M. (Eds) Manual de Fitopatologia: Doenças de plantas cultivadas. Vol.2. São Paulo. Agronômica Ceres. 1997. pp.736-757.
BEUKMAN, E.F. \& GOHEEN, A.C. Grape corky bark. In: Frazier, N.W. (Ed) Virus diseases of small fruits and grapevines. Berkeley. University of California/ Division Agricultural Sciences. 1970. pp.207209.

BONAVIA, M., DIGIARO, M., BOSCIA, D., BOARI, A. \& BOTTALICO, G. Studies on "corky rugose wood" of grapevine and on the diagnosis of grapevine virus B. Vitis 35:53-58. 1996.

Boscia, D., ASLOUJ, E., Elicio, V., SAVINO, V., CASTEllano, M.A. \& MARTElli, G.P. Production, characterization and use of monoclonal antibodies to grapevine virus A. Archives of Virology 127:185-194. 1992.

BOSCIA, D., SAVINO, V., MINAFRA, A., NAMBA, S. \& ELICIO, V. Properties of a filamentous virus isolated from grapevines affected by corky bark. Archives of Virology 130:109-120. 1993.

BOSCIA, D., MINAFRA, A. \& MARTELLI, G.P. Filamentous viruses of the grapevine: Putative trichovirus and capilloviruses. In: Monette, P.L. (Ed.) Filamentous Viruses of Woody Plants. Research Signpost. Trivandrum, India. 1997. pp.19-28.

CHOUEIRI, E., ABOU-GHANEM, N. \& BOSCIA, D. Grapevine virus $\mathrm{A}$ and grapevine virus $\mathrm{D}$ are serologically distantly related. Vitis 36:39-41. 1997.

GOHEEN, A.C. Corky Bark. In: Pearson, R.C. \& Goheen, A.C. (Eds.). Compendium of Grape Diseases. St. Paul.The American Phytopathological Society. 1988. pp.52-53.

GOIDANICH, G. \& CANOVA, A. La suberose corticale della vite. Una malatia da virus. Phytopathology Mediterranean 2:295-297. 1963.

HABILI, N. \& SYMONS, R.H. Grapevine viruses detected by Wait diagnostics in Australia. Extended Abstracts, $13^{\text {th }}$ Meeting of the International Council for the Study of Viruses and Virus-like Diseases of the Grapevine. Adelaide, Australia. 2000. pp.124-126.

HeVin, M., MOUTOUS, G. \& FOS, A. Transmission de la Flavescence doree par greffage en vert et presence du "Corky Bark" sur cepage corse (Nielluccio). Connaissance de la Vigne et du Vin 12:79-86. 1978

HEWITT, W.B. Some virus and virus-like diseases of grapevines. California Department of Agriculture Bulletin 43:47-64. 1954.

KUHN, G.B. Intumescimento dos ramos da videira ("Corky bark"), doença constatada no Rio Grande do Sul. Fitopatologia Brasileira 17:399-406. 1992.

KUNIYUKI, H. Identificação do fendilhamento cortical (corky bark) em vinhedos do Estado de São Paulo. Revista da Sociedade Brasileira de Fitopatologia 6:153-154. 1975.

KUNIYUKI, H. \& COSTA, A.S. Estudos sobre a virose fendilhamento cortical da videira em São Paulo. Fitopatologia Brasileira 7:71-81. 1982.

KUNIYUKI, H., REZENDE, J.A.M., KITAJIMA, E.W. \& BETTI, J.A. Detecção do Grapevine virus $B$ em videiras com a doença de fendilhamento cortical. Fitopatologia Brasileira 25:443. 2000.

MACKENZIE, D.J., MCLEAN, M.A., MUKERJI, S. \& GREEN, M. Improved RNA extraction for woody plants for the detection of viral pathogens by Reverse Transcription-Polymerase Chain Reaction. Plant Disease 81:222-226. 1997.

MARTELLI, G.P., MINAFRA, A. \& SALDARELLI, P. Vitivirus, a new genus of plant viruses. Archives of Virology 142:1929-1932. 1997.

MARTELLI, G.P. Grapevine virology highlights 1997-1999. Extended 


\section{A.E. Moreira et al.}

Abstracts, $13^{\text {th }}$ Meeting of the International Council for the Study of Viruses and Virus-like Diseases of the Grapevine. Adelaide, Australia. 2000. pp.1-5.

MINAFRA, A. Rugose wood grapevines. Extended Abstracts $13^{\text {th }}$ Meeting of the International Council for the Study of Viruses and Virus-like Diseases of the Grapevine. Adelaide, Australia. 2000. pp.3034.

MINAFRA, A., HADIDI, A. \& MARTELLI, G.P. Detection of grapevine closterovirus $\mathrm{A}$ in infected grapevine tissues by reverse transcription-polymerase chain reaction. Vitis 31: 221-227. 1992.

MINAFRA, A \& HADIDI, A. Sensitive detection of grapevine virus A, B or leafroll-associated III from viruliferous mealybugs and infected tissue by cDNA amplification. Journal of Virological Methods 46:175188. 1994.

NICKEL, O., FAJARDO, T.V.M., ARAGÃO, F.J.L., CHAGAS, C.M. \& KUHN, G.B. Detection and coat protein gene characterization of an isolate of Grapevine virus $B$ from corky bark-affected grapevines in Southern Brazil. Fitopatologia Brasileira 27:279-284. 2002.

PAPPU, S.S., BRAND, R. \& PAPPU, H.R. A polymerase chain reaction method adapted for selective amplification and cloning of 3 'sequences of potyviral genomes: application to dasheen mosaic virus. Journal of Virological Methods 41:9-20. 1993.

RUSSO, C.A.M. Como escolher genes para problemas filogenéticos específicos. In: Matioli, S.R. (Ed) Biologia Molecular e Evolução.
Holos Editora.2001. pp.130-136.

SALDARELLI, P., MINAFRA, A. \& MARTELLI, G.P. The nucleotide sequence and genomic organization of grapevine virus $\mathrm{B}$. Journal of General Virology 77:2645-2652. 1996.

SANTOS, M.T., MANSINHO, A., CORREIA, P.K., SEQUEIRA, O.A. \& NOLASCO, G. Multiple detection of grapevine filamentous viruses in Portugal, by RT-PCR from dsRNA templates. Extended Abstracts $13^{\text {th }}$ Meeting of the International Council for the Study of Viruses and Virus-like Diseases of the Grapevine. Adelaide, Australia. 2000. p. 129.

SAVINO, V., BOSCIA, D. \& MARTELLI, G.P. Rugose wood complex of grapevine: can grafting to Vitis indicators discriminate between diseases? In: $9^{\text {th }}$ Meeting of the International Council for the Study of Viruses and Virus-like Diseases of the Grapevine, Kiryat Anavim, 1989. pp.91-94.

TANAKA, S. Indexing grapes in Japan for viruses. Annals of the Phytopathological Society of Japan 42:192-196. 1976.

TANNE, E., DUBITSKY, E. \& BAZAK, H. Preliminary data on the effect of corky bark disease on Thompson Seedless vines grafted onvarious rootstocks. In: $10^{\text {th }}$ Meeting of International Council for the Study of Viruses and Virus-like Diseases of the Grapevine, Volos, 1990. pp.386-389.

TELIZ, D. \& GOHEEN, A.C. Diseases of grapevines in Mexico. Plant Disease Reporter 52:372-373. 1968. 